\title{
The Influence of Monetary Policy on Equity and Volatility Indices in the U.S. and Canada
}

\author{
Robert Killins ${ }^{1}$ \\ ${ }^{1}$ School of Accounting and Financial Services, Seneca College, Toronto, Canada \\ Correspondence: Robert Killins, School of Accounting and Financial Services, Seneca College, 1750 Finch Ave. \\ E. Toronto, Ontario, M2J 2X5 Canada. Tel: 416-491-5050 ext. 22671. E-mail: robert.killins@ senecacollege.ca
}

Received: January 18, 2016

Accepted: February 10, $2016 \quad$ Online Published: March 25, 2016

doi:10.5539/ijef.v8n4p132

URL: http://dx.doi.org/10.5539/ijef.v8n4p132

\begin{abstract}
This paper investigates the reaction of equity and volatility indices in the U.S. and Canada to changes in monetary policy by each respective country. The results confirm previous literature that suggests contractionary changes in monetary policy in the U.S. results in downward pressure on U.S. equity indices. Additionally, this research finds that monetary policy changes do not have any significant impact on the volatilely index in the U.S. (VIX). The results from the Canadian data show a much different picture. Contractionary changes of monetary policy in both Canada and the U.S. seem to drive Canadian equity markets in an upward manner. These monetary policy shocks also have a significant impact on volatilely indices in Canada. This research documents the dynamic relationship monetary policy has on equity markets in the U.S. and Canada.
\end{abstract}

Keywords: monetary policy, volatilily, equity

\section{Introduction}

Monetary policy is closely monitored in financial markets around the world. The effect of monetary policy on asset markets is of great importance to investors, policymakers, and researchers. While monetary policy primarily influences aggregate demand, the equity market serves as an important channel of the monetary transmission mechanism. Equity markets influence financial wealth, and thus consumption, investment and labor decisions. Mishkin (2007) documents the important role that asset and equity markets have in the transmission of monetary policy.

This study examines the reaction of equity and volatility indices to changes in monetary policy in the U.S. and Canada. There has been significant attention in both the academic and professional industry on the impacts central bank policy changes have on the economy and equity markets. Thorbecke (1997), Patelis (1997), Park and Ratti (2000), Rigobon and Sack (2004), Bernanke and Kuttner (2005) amongst others, have found that contractionary monetary policy puts downward pressure on equity markets. The impact monetary policy has on financial markets is not contained only to price changes or returns. Bomfim (2003), Nikkinen and Sahlstrom (2004), Bernanke and Kuttner (2005), Chen and Clements (2007) and Gospodinov and Jamali (2012) have investigated the impact monetary policy has on the volatility of equity markets. The evidence of these studies is still quite mixed as some draw conclusions that suggest contractionary monetary policy increases volatility while others conclude that it reduces market volatility.

This study draws data from two influential countries in North America to further investigate the impact monetary policy changes have on both equity and volatility indices. The U.S. and Canada are major trading partners, with the U.S. accounting for $82 \%$ of Canadian exports and $66 \%$ of its imports, and Canada accounting for $16.2 \%$ of U.S. exports and $14.9 \%$ of its imports in 2014. (Note 1) The two economies also exhibit strong interdependencies through the financial sector as suggested by Ambler (1989) and Schmitt-Grohé (1998), and therefore form a special case for the analysis of the international transmission of shocks across borders. With the strong relationship of trade and financial markets it is of great interest of academics and practitioners to understand the impact each country has on one and other.

Using monthly data spanning from 2002 to 2015 the results indicate that contractionary monetary policy shocks in the U.S. indeed put downward pressure on the equity markets in both the U.S and Canada supporting the previous literature outlined above. Secondly, these shocks do not have any significant impact on the VIX in the 
U.S. but do influence the Canadian VIX in a negative manner. Lastly, in contrast to previous findings, Canadian monetary policy shocks do in fact impact U.S. equity markets. Specifically, a one hundred bases point increases in Canada's main interest rate (the bank rate) corresponds to the S\&P500 index decreasing by approximately 6 percent.

When focusing on Canadian data, contractionary monetary policy shocks in both Canada and the U.S. adjust Canadian equity markets in an upward direction which is in contrast to the U.S. findings. The coefficients for the bank rate and federal funds rate are respectively 0.051 and 0.044 indicating a 100 basis point move of either rate adjusts the TSX60 index in an upward direction by close to 5 percent. These shocks also have significant impacts on the Canadian VIX index. In both regressions (OLS \& JOH-ML) a one hundred basis point increase to the bank rate reduces the Canadian VIX index by approximately 10 percent. Additionally, a 100 basis point increase in the federal funds rate results in decrease of the Canadian VIX by approximately 5 percent. These findings are in line with the previous literature of $\mathrm{Li}$ et al. (2010) but add to the research by incorporating option implied volatilely (VIX) as opposed to conditional volatilely.

This research contributes to the existing literature by revealing that the relationship between the U.S. and Canadian financial markets is dynamic and continuously evolving. This research shows that there is a long-run relationship between monetary policy changes and option implied volatilely measures such as the VIX indices in the U.S. and Canada. By incorporating the VIX indices this research adds to the relatively new literature focused on the volatility indices around the world and should be of interest not only to academics and policy-makers but also investors. Additionally, this paper adds to the dynamic impacts oil prices have on both economies. The results indicate that U.S. and Canadian equity markets respond uniquely to shocks in crude oil prices. Lastly, this research differs from some of the previous literature as I incorporate a vector-error correction model (VECM) that is most applicable when dealing with co-integrated macroeconomic variables. The remainder of the paper is organized as follows: Section II details the previous literature; Section III describes the data and presents descriptive statistics; Section IV presents the methodology employed; Section V presents the empirical results and discussion. Section VI presents the summary and conclusion.

\section{Literature Review}

According to the discounted cash flow model, stock prices are equal to the present value of expected future net cash flows. Monetary policy should then play an important role in determining equity returns by altering the discount rate used by investors or by changing the markets outlook on future economic activity. Policymakers try to modify economic behavior in ways that will help to achieve their ultimate objectives of price and market stability. Understanding the links between monetary policy and asset prices is thus crucially important for understanding the policy transmission mechanism.

The reaction of equity markets to monetary policy-related announcements from their domestic central banks vary from country to country. Focusing on U.S. data Thorbecke (1997), Patelis (1997), Park and Ratti (2000) find that contractionary changes in the federal funds rate leads to a fall in stock prices in their respective domestic market (U.S.). Rigobon and Sack (2004) find that a 25 basis point increases in the three-month interest rate results in a $1.7 \%$ decline in the S\&P500 index and a 2.4\% decline in the NASDAQ. Bernanke and Kuttner (2005) show that an unexpected 25 basis point decrease in the federal funds rate leads to a $1 \%$ increase in the level of stock prices on average. Internationally, Conover, et al. (1999) focused their attention on 16 countries around the world and found that restrictive domestic monetary policy has a negative impact on equity returns in all 16 countries examined. Conover, et al. further their study and examine the impact U.S. monetary policy has on other 15 countries in the study and conclude that foreign stock returns are related to U.S. monetary policy environments as many foreign markets exhibit significantly higher returns when the Federal Reserve is following an expansive versus a restrictive policy.

Empirical research focused on the U.S. leads to the conclusion that central banks monetary policy influences asset prices in a fairly predictable manner. There have been several studies focused on the reaction of Canadian economy to shocks in monetary related policy as well. Lastrapes (1998) provides cross-country evidence, and finds that in Canada an unanticipated 1\% decrease in the nominal money stock (M1) leads to a $1.6 \%$ fall in stock prices whereas in the U.S. a similar shock reduces stock prices by about 2.4\%. Siklos and Anusiewicz (1998) investigate the impact changes in money supply (M1) have on Canadian asset prices. Their results reveal that unexpectedly high U.S. money supply growth led to higher Canadian stock prices. Further, unexpectedly high money supply growth in Canada led to a fall in Canadian stock prices. Souki (2008) finds that shocks originating from the U.S. are more important in explaining fluctuations in Canadian economic variables than domestic shocks. Dufour and Tessier (2006) when focusing on the U.S. find no support for stock returns as a leading 
indicator of the macroeconomic variables or for stock returns being influenced by macroeconomic variables, except of changes in money supply. Changing their focus to Canada Dufour, et al. conclude that macroeconomic variables have little impact on asset prices and in fact asset prices may have an influence on macroeconomic variables such as output, prices, and interest rates. More recently, Li et al. (2010) find that an unanticipated 25 basis point increase in the federal funds rate leads to U.S. stock prices to decline by 0.55 percent, whereas a similar increase in the bank rate in Canada leads to stock prices to decline by only 0.0025 percent.

The impact monetary policy has on financial markets is not contained only to price changes or returns. Evidence is mixed on the impact that macroeconomic announcements have on the volatility of asset prices. Bomfim (2003) considers how U.S. equity volatility reacts to U.S. monetary policy announcements and reveals quite a significant increase in daily volatility conditional on the surprise element. Nikkinen and Sahlstrom (2004) found that implied volatility rose in the period prior to, and fell on the day of various macroeconomic announcements. Chen and Clements (2007) find that the VIX index falls on average by $2 \%$ on the day of Federal Open Market Committee meetings along with no significant movements on days prior to or after the meetings have been identified. Gospodinov and Jamali (2012) who use an event study approach similar to Bernanke and Kuttner (2005) investigated the effect of the federal funds rate surprises on the S\&P500 volatility and volatility risk premium and found that surprise changes in the target rate significantly increase volatility. Further, Kurov (2010) found that monetary policy actions in the U.S. have significant effect on investor sentiment. They conclude that investor sentiment plays a significant role in the effect of monetary policy on the stock market.

This study is in close relation with Li et al. (2010) and Souki (2008). Li et al. (2010) investigated the impact monetary policy shocks had on Canada and U.S. equity markets. Focusing on Canada, which in their paper is modelled as a small open economy they found that monetary policy shocks in the U.S. have significant impact on the Canadian stock prices and contribute substantially to their volatility. Further, they find that in response to an unanticipated 25 basis points increase in the domestic interest rate, stock prices in the U.S. decline by about $4 \%$ within seventeen months after the shock, and in Canada they only decline by about $0.8 \%$ within only four months after the shock. Souki (2008) show that U.S. monetary policy shocks tend to intensify both Canadian booms and recessions, while they have an overall stabilizing effect on Canadian prices over the period 1974-2004.

From the evidence outlined above the study takes the signaling approach to monetary policy and hypothesize that a tightening of monetary policy is a signal from the central bank that the economic conditions may be reaching a peak. This outlook from the central bank will potentially decrease projected future cash flows and increase the discount factor leading to aggregate levels of the stock market to be lower and potentially leading to higher levels of uncertainty resulting in increases in the volatility indices.

Additionally, this study incorporates other important macroeconomic variables to both respective countries. In a influential paper, Chen et al. (1986) tested whether shocks in macroeconomic variables influence the equity market. They find that industrial production and inflation among other variables are significant priced into equity markets. Industrial production measure the output of the country and thus should exhibit positive relationship with equity markets as outlined in the business cycle models.

The expected inflation hypothesis suggests that an unexpected increase in the money stock increases market participants' expectations of inflation. This leads to higher nominal interest rates and lowers the present value of a corporation's discounted cash flows. Therefore, stock prices should fall as inflation and interest rates rise. The empirical findings on the link between stock returns and inflation is mixed. Fama and Schwert (1977) amongst others find a negative relationship between these two variables. Bakshi and Chen (1996) amongst others suggest that the negative relationship could be caused by non-monetary factors. Hess and Lee (1999) shows that the relationship between stock returns and inflation could be either positive or negative.

The last variable I have incorporated in this research study is crude oil prices. During the sample period the U.S. was a net oil importer whereas Canada was a net oil exporter. Thus, the two countries my display different responses to shocks in oil prices. The evidence is somewhat mixed on the totally of the impact of oil shocks on each respective country. Killian (2009) aggregate analysis implies that, on average, in the long run, 22\% of the variation in aggregate stock returns during 1975-2006 can be attributed to the shocks that drive the crude oil market, making oil market fundamentals an important determinant of U.S. stock returns. Apergis and Miller (2009) find that international stock market returns do not respond in a large way to oil market shocks. Jimenez-Rodriquez and Herrera (2004) observe that a fall in oil prices have a positive impact on the US economy (after the first year following the oil shock) while it has a negative effect in Canada. From the existing literature I hypothesize that positive shocks in oil prices will have a positive effect on equity markets in Canada 
while having a negative impact on the U.S. equity markets.

\section{Data}

The variables for the Canadian sample are obtained from the CANSIMII database via Statistics Canada. The U.S. data is mainly sourced from the Board of Governor of the Federal Reserve System, downloaded from the Federal Reserve. The data are monthly and cover the period from January 2003 to September 2015. The study measures real output by the industrial production index (IP) in the U.S. and gross domestic product (GDP) in Canada, the price level by the consumer price index (CPI), and stock prices by a broad market index: S\&P 500 for the U.S. and S\&P-TSX for Canada. Further, I captured investor sentiment using the VIX index for the U.S. and the use the Canadian MVX/VIX for the Canadian data. The federal funds rate and the bank rate are respectively used for the U.S. and Canada to measure interest rate changes. I express all variable in natural logarithms in the analysis except for interest rates. A full list of the variable included in this study and their sources are included in appendix A.

Table 1 and 2 presents summary statistics of the time series variables used for the U.S. and Canadian variables respectively. Assessments of the shape of the distributions indicate that almost all the series are leptokurtic which suggests that these distributions are higher or more peaked. The Jarque-Bera tests reject the null $(\mathrm{P}<0.10)$ of the underlying normal distribution for most of the variables. Following Sarno and Thornton (2003) and Lizardo and Mollick (2009) the sample size of 163 observations and the effects of the central limit theorem, non-normality is not considered to be an problem for our research.

Table 1. U.S. summary statistics

\begin{tabular}{lccccccc}
\hline & USIP & USCPI & FF & USM2 & SP500 & USVIX & OIL \\
\hline Mean & 99.31 & 213.86 & 1.45 & 8457.65 & 1346.29 & 19.62 & 72.66 \\
Maximum & 107.92 & 238.10 & 5.26 & 12198.30 & 2111.94 & 62.64 & 133.88 \\
Minimum & 87.21 & 182.60 & .07 & 5769.5 & 757.13 & 10.82 & 28.11 \\
Std. Dev. & 4.98 & 17.23 & 1.82 & 1894.02 & 327.14 & 8.90 & 24.85 \\
Skewness & -0.31 & -0.28 & 1.10 & 0.38 & 0.77 & 2.35 & 0.01 \\
Kurtosis & 2.42 & 1.86 & 2.68 & 1.90 & 2.96 & 9.92 & 2.16 \\
Jarque-Bera & 5.81 & 37.01 & 19.37 & 32.34 & 11.46 & 67.69 & 10.44 \\
P-Value & $(0.054)$ & $(0.000)$ & $(0.001)$ & $(0.000)$ & $(0.003)$ & $(0.000)$ & $(0.005)$ \\
Observations & 153 & 153 & 153 & 153 & 153 & 153 & 153 \\
\hline
\end{tabular}

Note. USIP, USCPI, FF, USM2 SP500, USVIX, OIL denote U.S. Industrial Production, U.S. Consumer Price Index, U.S. Federal Funds Rate, U.S. Money Supply (M2), U.S. Standard \& Poor's 500 Index, U.S. VIX, and Crude Oil Prices (WTI).

Table 2. Canadian summary statistics

\begin{tabular}{lcccccc}
\hline & CGDP & CCPI & BR & TSX & CVIX & OIL \\
\hline Mean & 1486375 & 114.85 & 2.19 & 11786.46 & 18.11 & 72.66 \\
Maximum & 1657854 & 127.30 & 4.75 & 15625.73 & 61.27 & 133.88 \\
Minimum & 1303193 & 102.00 & 0.50 & 6343.29 & 9.72 & 28.11 \\
Std. Dev. & 99791.68 & 7.49 & 1.34 & 2288.92 & 8.18 & 24.85 \\
Skewness & 0.04 & -0.58 & 0.55 & -0.58 & 2.84 & 0.01 \\
Kurtosis & 2.09 & 1.80 & 1.93 & 2.46 & 13.09 & 2.16 \\
Jarque-Bera & 13.64 & 47.38 & 30.70 & 9.71 & 54.95 & 10.44 \\
P-Value & $(0.001)$ & $(0.000)$ & $(0.000)$ & $(0.008)$ & $(0.000)$ & $(0.005)$ \\
Observations & 153 & 153 & 153 & 153 & 153 & 153 \\
\hline
\end{tabular}

Note. CGDP, CCPI, BR, TSX, CVIX, OIL denote, Canadian Gross Domestic Product, Canadian Consumer Price Index, Canadian Bank Rate, Toronto Stock Exchange 60, Canadian VIX, and Crude Oil Prices (WTI).

Table 3 shows the unit root tests of our U.S. data series which include, USIP, USCPI, FF, USM2, SP500, USVIX, and OIL. I include the traditional augmented Dickey and Fuller (1979) test, in addition to the modified augmented Dickey and Fuller proposed by Elliott et al. (1996), and the Phillips-Perron Test (1988). We can conclude from the column on the right that all the above mentioned variables are consistent with I (1) process which suggest the series have a unit root in levels, but are stationary when first-differenced. These finding are consistent with numerous economic and financial series. 
Table 3. Unit root tests - U.S. data

\begin{tabular}{|c|c|c|c|c|c|}
\hline \multirow[t]{2}{*}{ Series } & \multirow[t]{2}{*}{ Trend? } & \multirow{2}{*}{$\begin{array}{l}\mathrm{ADF}(\mathrm{k}) \\
\mathrm{H}_{0} \text { : series has a unit root }\end{array}$} & \multirow{2}{*}{$\begin{array}{l}\text { DF-GLS(k) } \\
\mathrm{H}_{0} \text { : series has a unit root }\end{array}$} & \multirow{2}{*}{$\begin{array}{l}\mathrm{PP}(\mathrm{k}) \\
\mathrm{H}_{0} \text { : series has a unit root }\end{array}$} & \multirow[t]{2}{*}{ Determination } \\
\hline & & & & & \\
\hline USIP & Yes & $-2.883(5)$ & $-2.814(5)$ & $-1.404(5)$ & $\mathrm{I}(1)$ \\
\hline USCPI & Yes & $-1.533(3)$ & $-1.217(3)$ & $-1.419(3)$ & $\mathrm{I}(1)$ \\
\hline FF & Yes & $-1.908(2)$ & $-1.462(2)$ & $-0.977(2)$ & $\mathrm{I}(1)$ \\
\hline USM2 & Yes & $-2.736(5)$ & $-1.750(5)$ & $-2.126(5)$ & $\mathrm{I}(1)$ \\
\hline SP500 & Yes & $-1.441(2)$ & $-1.695(2)$ & $-2.610(2)$ & $\mathrm{I}(1)$ \\
\hline USVIX & Yes & $-3.058(1)^{*}$ & $-2.603(1)^{*}$ & $-2.895(1)$ & $\mathrm{I}(1)$ \\
\hline OIL & Yes & $-2.448(3)$ & $-2.106(3)$ & $-1.702(3)$ & $\mathrm{I}(1)$ \\
\hline$\Delta \mathrm{USIP}$ & No & $-2.778(4)^{*}$ & $-2.767(4)^{*}$ & $-9.919(4)^{* * *}$ & $\mathrm{I}(0)$ \\
\hline$\triangle \mathrm{USCPI}$ & No & $-6.702(2)^{* * *}$ & $-6.385(2)^{* * *}$ & $-7.539(2)^{* * *}$ & $\mathrm{I}(0)$ \\
\hline$\Delta \mathrm{FF}$ & No & $-4.381(1)^{* * *}$ & $-4.381(1)^{* * *}$ & $-5.034(1)^{* * *}$ & $\mathrm{I}(0)$ \\
\hline$\Delta \mathrm{USM} 2$ & No & $-4.971(4)^{* * *}$ & $-4.715(4)^{* *}$ & $-9.015(4)^{* * *}$ & $\mathrm{I}(0)$ \\
\hline$\Delta \mathrm{SP} 500$ & No & $-7.658(1)^{* * *}$ & $-5.171(1)^{* * *}$ & $-9.251(1)^{* * *}$ & $\mathrm{I}(0)$ \\
\hline$\Delta$ USVIX & No & $-11.947(0)^{* * *}$ & $-7.650(0)^{* * *}$ & $-7.539(0)^{* * *}$ & $\mathrm{I}(0)$ \\
\hline$\Delta \mathrm{OIL}$ & No & $-6.241(2)^{* * *}$ & $-6.198(2)^{* * *}$ & $-8.904(2)^{* * *}$ & $\mathrm{I}(0)$ \\
\hline
\end{tabular}

Note. Data are of monthly frequency from 2003:01 to 2015:09. The symbol $\Delta$ refers to the first difference of the original series. ADF (k) refers to the Augmented Dickey-Fuller t-tests for unit roots, in which the null is that the series contains a unit root. The lag length (k) is chosen by the Campbell-Perron data dependent procedure. DF-GLS (k) refers to the modified ADP test proposed by Elliott et al. (1996). The PP (k) refers to the Phillips-Perron in which the null is that he series contains a unit root.

*Significance at $10 \%$ level.

**Significance at $5 \%$ level.

*** Significance at $1 \%$ level.

Before I formally present our vector-error correction model, it is useful to discuss several background issues concerning the choice of the sample period, and monetary policy instruments. I start the sample period from January 2003 because of two important considerations: (i) the continuity and similarity of monetary policy operating procedures in the Canadian and U.S. economies, and (ii) the growing integration of the two economies since the early 1990's. Since 1988 both economies have been marked by continuity and similarity in terms of their monetary policy instruments, objectives, and low inflation. I use the federal funds rate in the U.S. and the overnight interest rate in Canada as the monetary policy instrument. Since the early 1990's, there has also been an increasing integration of the Canadian and U.S. economies. The 1988 free trade agreement has accelerated and bolstered the already extensive economic integration of these two economies. Of course, given the significant difference in the sizes of these economies, the U.S. economy has a considerably larger influence on the Canadian economy. The financial sectors in both the U.S. and Canada are also highly integrated.

\section{Methodology}

This study uses a vector-error correction model (VECM) in order to help determine the relationships present among the equity markets, VIX indices and the economic/monetary variables of each respective country. This research is similar to Dufour and Tessier (2006) and Li et al. (2010) but I take a somewhat different methodological approach to testing the impact interest rates have on stock indices and further investigate how monetary policy changes impact consumer sentiment indices (VIX). I model this relationship within a general equilibrium framework in which major macroeconomic variables interact contemporaneously and over time.

The testing procedure for the identification of causal directions turn out to be more difficult when the series are cointegrated I (1) processes. The usual Granger causality tests are not suitable because statistically the existence of cointegration rules out non-causality between the series (Granger \& Lin, 1995). As pointed out by Miller (1991), if two variables are cointegrated then there must be temporal causality in the Granger sense between them in at least one direction. The cointegration of unit root processes may then have two forces that are driving changes in the series. One factor producing the change could be the response of one series due to changes in another series (i.e., the cointegrating coefficient). The second factor producing the change could be the correction by the series to its own equilibrium track (i.e. feedback coefficients). As a result, conventional Granger causality test are mis-specified if the feedback coefficient is not taken into account, which may be done using a VECM in the following form:

If the long-run impact matrix in (1) is less than full rank, it can be decomposed as follows: 


$$
\begin{gathered}
\left.\Delta y_{t}=n y_{t-1}+\sum_{i=1}^{k-1} \Gamma_{i} \Delta y_{t-i}+\Phi d_{t}+\varepsilon_{t}, t=1, \ldots, T\right] \\
\Pi=\alpha \beta
\end{gathered}
$$

where $\alpha$ is an $n \times r$ matrix of feedback coefficients and $\beta \square$ is an $r \times n$ matrix of cointegrating coefficients. The mis-specification of the Granger causality test is due to the fact that if the nonstationary series are cointegrated, a Granger causality test would involve the coefficients of $\Pi(2)$, and since these coefficients multiply nonstationary variables, it is not suitable to use an F-statistic to test for Granger causality. Block exogeneity tests are also not suitable if nonstationary variables are cointegrated (Enders, 2004). The suggestion is that if the long-run impact matrix $\Pi$ in (1) is less than full rank, it can be decomposed as in (2), which yields two foundations of causality: the cointegrating coefficients and the feedback coefficients. The path and scale of causation would be a function of the size and direction of those metrics. If it is found that $(\alpha)$ is negative and statistically significant, we could determine that the direction of causality goes from the predictors to the predicted variables in the model. Testing for causality in case of regression with integrated I (1) variables involves testing for long-run causality as suggested by Engle et al. (1983), followed by estimation of $\alpha$ under constraint. The tests can be done using the likelihood-ratio procedures as in Johansen and Juselius (1990) by adding further restrictions on the feedback coefficient.

The U.S. VECM models consists of real output (USIP), the price level (USCPI), the federal funds rate (FF), and the price of oil (OIL), which are standard in the empirical monetary business-cycle models of the U.S., plus stock prices (SP500) and market volatility or sentiment (USVIX) which are included to control for (stock market driven) effects. The Canadian VECM model, on the other hand, consists of real output (CGDP), the price level (CCPI), the overnight interest rate (BR), and crude oil prices (OIL) which are also standard in the Mundell-Fleming-type models for open economies, plus stock prices (TSX60) and market volatility/sentiment (CVIX) as the dependent variable. These models are in-line with the previous research of Li et al. (2010) amongst others who investigate the relationship between monetary policy and asset prices between these two countries.

When output (USIP or CGDP) moves higher this signals growth in the overall economy and should spur investment in the markets, thus we should expect $\beta_{1}$ to be positive. The exogenous oil price (OIL) variable is predicted to be positive as demand for oil may signal robust economic activity. When inflation (CPI) moves higher, the required rate of return on equity should increase the intrinsic value of existing equities, ceteris paribus, should decline. The suggestion of this is that we expect real output shocks to dominate monetary shocks. (Note 2) The same applies to the interest rate variables (FF and BR) thus the coefficients should be negative. In model 5, 6, 7 and 8 we now use the VIX index as the dependent variable holding the independent variables as in the previous models. I predict $\beta_{1}$ to be negative as increased output should soften the volatilely in the markets. The exogenous variable oil prices (OIL) should be attached to a positive coefficient when predicting the VIX as increase in oil prices may drive consumer sentiment and market volatilely in an upward manner. Results for $\beta_{3}$ should show a positive coefficients as increased inflationary fears may impact consumer sentiment and market volatilely in a negative manner. The coefficients attached to the monetary policy variables (FF, BR) are predicted to be positive. Changes in these main interest rates could signal uncertainty in the financial markets leading to higher volatilely.

U.S. Model(s)

$$
\begin{aligned}
& S 500_{t}=\beta_{1} U_{S I P}+\beta_{2} \text { OIL }_{t}+\beta 3 \text { USCPI }_{t}+\varepsilon_{t} \\
& S P 500_{t}=\beta_{1} U S I P_{t}+\beta_{2} \text { OIL }_{t}+\beta 3 U S C P I_{t}+\beta_{4} F F_{t}+\varepsilon_{t} \\
& S 5000_{t}=\beta_{1} U_{S I P_{t}}+\beta_{2} \text { OIL }_{t}+\beta 3 U S M 2_{t}+\varepsilon_{t} \\
& S P 500_{t}=\beta_{1} U S I P_{t}+\beta_{2} \text { OIL }_{t}+\beta_{3} B R_{t}+\varepsilon_{t} \\
& \text { USVIX }=\beta_{1} \text { USIP }_{t}+\beta_{2} \mathrm{OIL}_{t}+\beta_{3} \text { USCPIt }+\varepsilon_{t} \\
& U S V I X_{t}=\beta_{1} U_{S I P_{t}}+\beta_{2} \mathrm{OIL}_{t}+\beta_{3} U S C P I_{t}+\beta_{4} F F+\varepsilon_{t} \\
& U S V I X_{t}=\beta_{1} U_{S I P}+\beta_{2} \operatorname{OIL}_{t}+\beta_{3} U S M 2_{t}+\varepsilon_{t} \\
& U S V I X_{t}=\beta_{1} U S I P t+\beta_{2} O_{L} L_{t}+\beta_{3} B R_{t}+\varepsilon_{t}
\end{aligned}
$$

Canadian Model(s)

$$
\begin{aligned}
& T S X_{t}=\beta_{1} C G D P_{t}+\beta_{2} \mathrm{OIL}_{t}+\beta_{3} C C P I_{t}+\varepsilon_{t} \\
& T S X_{t}=\beta_{I} C G D P_{t}+\beta_{2} \text { OIL }_{t}+\beta_{3} B R+\varepsilon_{t} \\
& T S X_{t}=\beta_{1} C G D P_{t}+\beta_{2} \text { OIL }_{t}+\beta_{3} F F_{t}+\varepsilon_{t}
\end{aligned}
$$




$$
\begin{gathered}
T S X_{t}=\beta_{I} C G D P_{t}+\beta_{2} \text { OIL }_{t}+\beta_{3} U_{S M 2}+\varepsilon_{t} \\
C V I X=\beta_{I} C G D P_{t}+\beta_{2} \text { OIL }_{t}+\beta_{3} C C P I_{t}+\varepsilon_{t} \\
C V I X_{t}=\beta_{1} C G D P_{t}+\beta_{2} \text { OIL }_{t}+\beta_{3} B R_{t}+\varepsilon_{t} \\
C V I X_{t}=\beta_{1} C G D P_{t}+\beta_{2} \text { OIL }_{t}+\beta_{3} F F_{t}+\varepsilon_{t} \\
\text { CVIX }_{t}=\beta_{1} C G D P_{t}+\beta_{2} \text { OIL }_{t}+\beta_{3} U_{S M 2_{t}}+\varepsilon_{t}
\end{gathered}
$$

The model(s) outlined above are estimated by OLS and by the multivariate maximum likelihood procedure (JOH-ML) of Johansen, 1988, 1991. Due to the fact estimations using OLS may exhibit heteroscedasticity and autocorrelation resulting in spuriousness relationships I use the Newey and West (1987) variance-covariance estimator that is reliable with the presence of both heteroscedasticity and autocorrelation.

\section{U.S. Results}

The next step in the analysis requires the testing of the existence of a long-run relationship among the variables in the empirical models.

Table 4. Cointegration tests - U.S. data

\begin{tabular}{lccccc}
\hline Estimation Sample/Variables & Lags & Trace & 0.05 Trace C.V & Max-Eigen & 0.05 Max-Eigen C.V. \\
\hline Model (1) & 2 & $89.015 * * * *$ & 68.52 & $53.113 * * *$ & 33.46 \\
Model (2) & 2 & $120.454 * * *$ & 94.15 & $57.686^{* * *}$ & 39.37 \\
Model (3) & 1 & $104.676^{* * *}$ & 68.52 & $51.936 * * *$ & 33.46 \\
Model (4) & 1 & $102.65 * * *$ & 68.52 & $50.452 * * *$ & 33.46 \\
Model (5) & 1 & $81.296^{* * *}$ & 68.52 & $43.079 * * *$ & 33.46 \\
Model (6) & 2 & $112.926 * * *$ & 94.15 & $50.064 * * *$ & 39.37 \\
Model (7) & 1 & $89.361 * * *$ & 68.52 & $41.146 * * *$ & 33.46 \\
Model (8) & 1 & $82.675^{* * *}$ & 68.52 & $44.952 * * *$ & 33.46 \\
\hline
\end{tabular}

*** Rejection of the null of no cointegration at $1 \%$ level. The lag length is chosen by the AIC, SC or HQ criterion.

Table 4 shows robust support for the presence of a long-run relationship between SP500, USIP, USCPI, OIL, FF, and USM2 by the Johansen $(1988,1991)$ trace and maximum eigenvalue tests for the U.S. sample. The null hypothesis of no cointegration is definitively rejected at conventional significance levels. In the second analysis of our study focusing on U.S. VIX index there is also strong support indicating a long-run relationship amongst the independent variables listed above and U.S. VIX index.

The results from Table 4 allow the study to continue to examine the relationship amongst the variables by estimating models (1) through (8) using OLS and JOH-ML. Models (1) through (8) are cointegrating, deviations of SP500 and USVIX from a linear combination of the independent variables of the various models are in turn

\begin{tabular}{|c|c|c|c|c|c|c|c|}
\hline Dependent Variable & USIP & OIL & USCPI & $\mathrm{FF}$ & USM2 & $\mathrm{BR}$ & $\mathrm{R}^{2}$ \\
\hline (1) & $3.392 * * *$ & $-0.093 * *$ & $1.376^{* * *}$ & & & & 0.92 \\
\hline SP500 & $(.2178)$ & $(.0699)$ & $(.1576)$ & & & & \\
\hline (2) & $3.690 * * *$ & -0.061 & $1.031 * * *$ & $-0.014 *$ & & & 0.92 \\
\hline SP500 & $(.3948)$ & $(.0499)$ & $(.3466)$ & $(.0085)$ & & & \\
\hline (3) & $3.336 * * *$ & -0.032 & & & $0.4589 * * *$ & & 0.91 \\
\hline SP500 & $(.2362)$ & $(.0276)$ & & & $(.0441)$ & & \\
\hline (4) & $4.520 * * *$ & -0.016 & & & & $-0.067 * * *$ & 0.91 \\
\hline SP500 & $(.1966)$ & $(.0231)$ & & & & $(.0056)$ & \\
\hline (5) & $-4 . .441 * * *$ & -0.105 & $1.627 * *$ & & & & 0.34 \\
\hline USVIX & (.7986) & $(.1503)$ & (.7209) & & & & \\
\hline (6) & $-4.817 * * *$ & -0.146 & $2.062 *$ & 0.1785 & & & 0.34 \\
\hline USVIX & (1.063) & (.1818) & (1.134) & $(.0326)$ & & & \\
\hline
\end{tabular}
stationary. Meaning that the residuals from the estimations are I $(0)$ and estimated parameters are not spurious. As Granger (1986) states, "A test of cointegration can be thought of as a pre-test to avoid spurious regression situations."

Table 5. U.S cointegrating coefficient estimates of models for the full sample: 2003:01 to 2015:09 (OLS) 


\begin{tabular}{|c|c|c|c|c|c|}
\hline (7) & $-4 . .332 * * *$ & 0.0212 & 0.3626 & & 0.31 \\
\hline USVIX & $(.8135)$ & $(.1241)$ & $(.2293)$ & & \\
\hline (8) & $-3.841^{* * * *}$ & 0.112 & & -0.013 & 0.28 \\
\hline USVIX & $(.7616)$ & $(.1087)$ & & $(.0331)$ & \\
\hline
\end{tabular}

The constant term was included in the estimation but not reported. Newey-West heteroscedasticity and autocorrelation (HAC) standard errors are reported in parenthesis for the OLS estimates. Since the deviations of USSP500 and USVIX are stationary the results presented are considered to adequately represent the long-run relationship between U.S. stock market performance and the included independent variables listed.

*Significance at $10 \%$ level.

**Significance at $5 \%$ level.

$* * *$ Significance at $1 \%$ level.

Cointegration coefficient estimates using OLS method for the U.S. models are shown in Table 5. In models (1) through (4) the $\beta$ coefficient estimate for USIP is compatible with the theoretical signs predicted. A positive one unit change in USIP provides approximately $3.3 \%$ to $4.5 \%$ uptick in the S\&P500. The $\beta$ coefficient estimate for OIL indicates a negative relationship between oil and the equity market. Although the negative relationship is indeed in line with the hypothesis formulated for the U.S. sample this relationship does not seem to be statistically significant at conventional statistical levels. The $\beta$ coefficient estimate for inflation indicates a significant positive relationship between inflation and the equity index S\&P500.

Turing our attention to the monetary policy variables, I find significant results for all three variables included. The first monetary coefficient of interest was focused on the federal funds (FF) rate. Positive shocks to the federal funds rates have a significant negative impact on the equity market in the U.S. with a coefficient of -0.014. Secondly, positive changes in the U.S. money supply (USM2) have a positive influence on equity markets with a coefficient of 0.459. Lastly, positive shocks to the Canadian bank rate correspond to a negative reaction in U.S. equity markets with a coefficient of -0.067 .

The second panel in table 5 present the results focused on the U.S. VIX index. The $\beta$ coefficient estimates for USIP suggests that as USIP inches higher this results in lowering the U.S. VIX index significantly as the coefficients range from -3.841 to -4.817 and are all significant at conventional statistical levels. The $\beta$ coefficient estimates for OIL again show no significant impact when regressed on USVIX. Positive changes in inflation lead to increases in the U.S. VIX index. Focusing on the monetary variables of interest (FF, BR, USM2) all three do not seem to have a significant impact on the U.S. VIX.

Table 6. U.S. cointegrating coefficient estimates of models for the full sample: 2003:01 to 2015:09 (JOH-ML)

\begin{tabular}{|c|c|c|c|c|c|c|c|c|}
\hline Dependent Variable & USIP & OIL & USCPI & FF & USM2 & $\mathrm{BR}$ & $\mathrm{R}^{2}$ & $\mathrm{ECM}$ \\
\hline (1) & $3.323 * * *$ & $-0.156 * * *$ & $1.546^{* * *}$ & & & & .32 & $-0.1558 * * *$ \\
\hline SP500 & $(.1816)$ & $(.0352)$ & $(.1676)$ & & & & & \\
\hline (2) & $3.589 * * *$ & $-0.134 * * *$ & $1.233 * * *$ & $-0.013 *$ & & & .33 & $-0.1671 * * *$ \\
\hline SP500 & $(.2350)$ & $(.0387)$ & $(.2476)$ & $(.0075)$ & & & & \\
\hline (3) & $3.345^{* * *}$ & $-0.074 * * *$ & & & $0.4834 * * *$ & & .32 & $-0.2103^{* * * *}$ \\
\hline SP500 & $(.1621)$ & $(.0257)$ & & & $(.0452)$ & & & \\
\hline (4) & $4.538 * * *$ & -0.007 & & & & $-0.061 * * *$ & .27 & $-0.1544 * * *$ \\
\hline SP500 & $(.2093)$ & $(.0271)$ & & & & $(.0076)$ & & \\
\hline (5) & $-4.113 * * *$ & 0.051 & $1.275^{* * *}$ & & & & .14 & $-0.1956^{* * * *}$ \\
\hline USVIX & $(.800)$ & $(0.1540)$ & $(.7342)$ & & & & & \\
\hline (6) & $-4.941 * * *$ & 0.126 & $2.050 * *$ & 0.019 & & & .15 & $-0.2673 * *$ \\
\hline USVIX & $(.8285)$ & $(.0898)$ & $(.8711)$ & $(.0266)$ & & & & \\
\hline (7) & $-4.447 * * *$ & 0.124 & & & 0.3908 & & .15 & $-0.2006^{* * * *}$ \\
\hline USVIX & $(.7946)$ & $(.1254)$ & & & $(.2191)$ & & & \\
\hline (8) & $-3.654 * * *$ & $0.205^{*}$ & & & & -0.034 & .15 & $-0.1893 * * *$ \\
\hline USVIX & $(.8673)$ & $(.1124)$ & & & & $(.0314)$ & & \\
\hline
\end{tabular}

The method of estimation is the vector error correction model with two lags. The lag length was chosen by the HQ, SC, or AIC Criterion. In the first-stage the Johansen cointegration method is used for estimation of the long-run vector. In the second-stage, residuals from the first-stage are used in differenced form.

*Significance at $10 \%$ level.

**Significance at $5 \%$ level.

$* * *$ Significance at $1 \%$ level. 
Table 6 presents the estimation of the models (1) through (8) presents the results of the JOH-ML. The coefficients for the various independent variables maintain their directional (+/-) relationships as in the OLS regressions. The monetary policy variables FF, USM2, BR all maintain their significance related to the S\&P 500 while showing no significant impact on the VIX index. Concentrating on the far right column, which identifies the error-correction term (feedback coefficient), we can confirm that the feedback adjustments are negative and statistically significant for all models. The null hypothesis of these feedback adjustments being zero can be rejected at conventional statistical levels. When abnormalities from the long-run equilibrium occur it is mainly the equity index that adjusts to restore long-run equilibrium rather than the included predicting variables. In table 6 the VECM indicates that if the equity-market performance was higher than expected in the last period, in the current period it would be decreased by $1.54 \%$ to $2.10 \%$ to reestablish the long-run relationship between the stock-market performance and the included independent variables. The latter half of table 6 indicates that if the USVIX index was higher than expected in the last period, in the current period it would be decreased by $1.89 \%$ to $2.67 \%$ to restore the long-run relationship between the USVIX and the independent variables. These findings suggests that the independent variables in the model(s) are (weakly) exogenous. The second implication is that unidirectional Granger causality going from the significant independent variables to the predicted variables is sustained. Overall this study finds long-run and short-run causation for industrial production (USIP), inflation (USCPI) and interest rates (FF, BR) to the equity index in the U.S. (S\&P500) and finds long-run and short-run causation for only industrial production (USIP) and inflation (USCPI) to the volatility index in the U.S. (USVIX).

\section{Canadian Results}

Table 7 shows the unit root tests of the Canadian data series which include, CGDP, CCPI, OIL, BR, TSX, and CVIX. As in the U.S. data we include the traditional augmented Dickey and Fuller (1979) test, in addition to the modified augmented Dickey and Fuller proposed by Elliott et al. (1996), and the Phillips-Perron Test (1988). We can conclude from the column on the right that all the above mentioned variables are consistent with I (1) process which suggest the series have a unit root in levels, but are stationary when first-differenced. These finding are consistent with the findings in the U.S results.

Table 7. Unit Root tsts - Canadian data

\begin{tabular}{|c|c|c|c|c|c|}
\hline Series & Trend? & $\begin{array}{l}\mathrm{ADF}(\mathrm{k}) \\
\mathrm{H}_{0} \text { : series has a unit root }\end{array}$ & $\begin{array}{l}\text { DF-GLS(k) } \\
\mathrm{H}_{0} \text { : series has a unit root }\end{array}$ & $\begin{array}{l}\mathrm{PP}(\mathrm{k}) \\
\mathrm{H}_{0} \text { : series has a unit root }\end{array}$ & Determination \\
\hline CGDP & Yes & $-1.183(4)$ & $-2.449(4)$ & $-0.981(4)$ & $\mathrm{I}(1)$ \\
\hline CCPI & Yes & $-0.587(2)$ & $-3.841(2)^{* *}$ & $-0.822(2)$ & $\mathrm{I}(1)$ \\
\hline BR & Yes & $-1.558(4)$ & $-2.030(4)$ & $-0.909(4)$ & $\mathrm{I}(1)$ \\
\hline TSX & Yes & $-3.074(2)$ & $-1.785(2)$ & $-2.582(2)^{*}$ & $\mathrm{I}(1)$ \\
\hline CVIX & Yes & $-2.974(1)$ & $-2.787(1)^{*}$ & $-2.837(1)^{*}$ & $\mathrm{I}(1)$ \\
\hline OIL & Yes & $-2.448(3)$ & $-2.106(3)$ & $-1.702(3)$ & $\mathrm{I}(1)$ \\
\hline$\triangle \mathrm{CGDP}$ & No & $-4.044(3)^{* * *}$ & $-4.057(3)^{* * *}$ & $-10.668(3)^{* * *}$ & $\mathrm{I}(0)$ \\
\hline$\Delta \mathrm{CCPI}$ & No & $-8.200(1)^{* * *}$ & $-5.881(1)^{* * *}$ & $-9.998(1)^{* * *}$ & $\mathrm{I}(0)$ \\
\hline$\Delta \mathrm{BR}$ & No & $-4.133(3)^{* * *}$ & $-4.125(3)^{* * *}$ & $-8.729(3)^{* * *}$ & $\mathrm{I}(0)$ \\
\hline$\Delta \mathrm{TSX}$ & No & $-6.576(1)^{* * *}$ & $-6.515(1)^{* * *}$ & $-9.635(1)^{* * *}$ & $\mathrm{I}(0)$ \\
\hline$\Delta \mathrm{CVIX}$ & No & $-11.999(0)^{* * *}$ & $-10.841(0) * * *$ & $-11.999(0)^{* * *}$ & $\mathrm{I}(0)$ \\
\hline$\Delta \mathrm{OIL}$ & No & $-6.241(2)^{* * *}$ & $-6.198(2)^{* * *}$ & $-8.904(2)^{* * *}$ & $\mathrm{I}(0)$ \\
\hline
\end{tabular}

Note. Data are of monthly frequency from 2003:01 to 2015:09. The symbol $\Delta$ refers to the first difference of the original series. I include the deterministic trend only when testing in levels. $\mathrm{ADF}(\mathrm{k})$ refers to the Augmented Dickey-Fuller t-tests for unit roots, in which the null is that the series contains a unit root. The lag length $(\mathrm{k})$ is chosen by the Campbell-Perron data dependent procedure. DF-GLS (k) refers to the modified ADP test proposed by Elliott, et al. (1996). The PP (k) refers to the Phillips-Perron in which the null is that he series contains a unit root.

*Significance at $10 \%$ level.

**Significance at $5 \%$ level.

***Significance at $1 \%$ level. 
Table 8. Cointegration tests - Canadian data

\begin{tabular}{lccccc}
\hline Estimation Sample/Variables & Lags & Trace & 0.05 Trace C.V & Max-Eigen & 0.05 Max-Eigen C.V. \\
\hline Model (1) & 2 & $104.860^{* * *}$ & 68.52 & $61.399^{* * *}$ & 33.46 \\
Model (2) & 2 & $139.326^{* * *}$ & 68.52 & $65.458^{* * *}$ & 33.46 \\
Model (3) & 2 & $151.927 * * *$ & 68.52 & $70.542^{* * *}$ & 33.46 \\
Model (4) & 2 & $145.453^{* * *}$ & 68.52 & $67.514 * * *$ & 33.46 \\
Model (5) & 1 & $135.977^{* * *}$ & 68.52 & $61.050^{* * *}$ & 33.46 \\
Model (6) & 1 & $160.160^{* * *}$ & 68.52 & $58.538^{* * *}$ & 33.46 \\
Model (7) & 1 & $159.645^{* * *}$ & 68.52 & $61.254^{* * *}$ & 33.46 \\
Model (8) & 1 & $155.830^{* * *}$ & 68.52 & $58.991^{* * *}$ & 33.46 \\
\hline
\end{tabular}

*** Rejection of the null of no cointegration at $1 \%$ level. The lag length is chosen by the HQ, SC or AIC criterion.

Table 8 shows support for the presence of a long-run relationship between TSX, CGDP, CCPI, OIL, BR, and two U.S. monetary variables (FF, USM2) by the Johansen $(1988,1991)$ trace and maximum eigenvalue tests for the Canadian sample. The null hypothesis of no cointegration is definitively rejected at conventional significance levels. Additionally, the Johansen trace and eigenvalue show a long-run relationship among the predictors above and the Canadian VIX index as well.

Table 9. Canadian cointegrating coefficient estimates of models for the full sample: 2003:01 to 2015:09 (OLS)

\begin{tabular}{|c|c|c|c|c|c|c|c|}
\hline Dependent Variable & CGDP & OIL & CCPI & $\mathrm{BR}$ & $\mathrm{FF}$ & USM2 & $\mathrm{R}^{2}$ \\
\hline (1) & $5.121 * * *$ & $0.2396 * * *$ & $-3.572 * * *$ & & & & .85 \\
\hline TSX & $(.8460)$ & $(.0406)$ & $(.8401)$ & & & & \\
\hline (2) & $2.464 * *$ & $0.184 * * *$ & & $0.051 * * *$ & & & .87 \\
\hline TSX & $(.2705)$ & $(.0409)$ & & $(.0091)$ & & & \\
\hline (3) & $2.504 * * * *$ & $0.163 * * *$ & & & $0.044 * * *$ & & .90 \\
\hline TSX & $(.2216)$ & $(.0371)$ & & & $(.0046)$ & & \\
\hline (4) & $5.693 * * *$ & $0.138 * * *$ & & & & $-1.122 * * *$ & .90 \\
\hline TSX & $(.9502)$ & $(.0423)$ & & & & $(.2516)$ & \\
\hline (5) & $-9.424 * * *$ & 0.035 & $9.963 * * *$ & & & & .34 \\
\hline CVIX & $(2.307)$ & $(.1458)$ & $(2.561)$ & & & & \\
\hline (6) & -0.890 & 0.123 & & $-0.058^{*}$ & & & \\
\hline CVIX & $(.7217)$ & $(.1331)$ & & $(.0307)$ & & & \\
\hline (7) & -0.822 & 0.138 & & & $-0.043 * *$ & & .26 \\
\hline CVIX & $(.6678)$ & (.1317) & & & $(.0186)$ & & \\
\hline (8) & -1.345 & 0.206 & & & & $1.680^{* *}$ & \\
\hline CVIX & $(.7892)$ & (.12990 & & & & (.7003) & \\
\hline
\end{tabular}

The constant term was included in the estimation but not reported. Newey-West heteroscedasticity and autocorrelation (HAC) standard errors are reported in parenthesis for the OLS estimates. Since the deviations of TSX and CVIX are stationary the results presented are considered to adequately represent the long-run relationship between Canadian stock market performance and the included independent variables listed. *Significance at $10 \%$ level.

$* *$ Significance at $5 \%$ level.

$* * *$ Significance at $1 \%$ level.

Tables 9 and 10 show the cointegrating coefficient estimates for the Canadian models. As in the U.S. models output, as measured by GDP in Canada has a significant positive impact on the equity market in Canada. The similarities between the two countries do no go much further. 
Table 10. Canadian cointegrating coefficient estimates of models for the full sample: 2003:01 to 2015:09 (JOH-ML)

\begin{tabular}{|c|c|c|c|c|c|c|c|c|}
\hline Dependent Variable & CGDP & OIL & CCPI & $\mathrm{BR}$ & $\mathrm{FF}$ & USM2 & $\mathrm{R}^{2}$ & $\mathrm{ECM}$ \\
\hline (1) & $7.037 * * *$ & 0.031 & $-4.861 * * *$ & & & & .20 & -0.0992 \\
\hline TSX & $(1.517)$ & $(.0832)$ & $(1.537)$ & & & & & \\
\hline (2) & $3.160 * * *$ & 0.010 & & $0.059 * * *$ & & & .16 & -0.1042 \\
\hline TSX & $(.4732)$ & $(.0738)$ & & $(.0164))$ & & & & \\
\hline (3) & $3.141 * * *$ & 0.028 & & & $0.045^{* * *}$ & & .20 & -0.1517 \\
\hline TSX & $(.3277)$ & $(.0544)$ & & & $(.0081)$ & & & \\
\hline (4) & $7.111 * * *$ & 0.018 & & & & $1.357 * * *$ & .18 & -0.1101 \\
\hline TSX & $(1.096)$ & $(.0651)$ & & & & $(.2929)$ & & \\
\hline (5) & $-13.396^{* *}$ & $0.392 * * *$ & $12.205^{* * *}$ & & & & .08 & -0.1338 \\
\hline CVIX & $(2.160)$ & $(.117)$ & $(2.192)$ & & & & & \\
\hline (6) & $-3.408 * * *$ & $0.541 * * *$ & & $-0.106^{* * *}$ & & & .07 & -0.1234 \\
\hline CVIX & $(.9786)$ & $(.516)$ & & $(.0341)$ & & & & \\
\hline (7) & $-2.995 * * *$ & $0.581 * * *$ & & & $-0.054 * * *$ & & .07 & -0.1431 \\
\hline CVIX & $(.1 .025)$ & $(.1697)$ & & & $(.0255)$ & & & \\
\hline (8) & $-12.325^{* *}$ & $0.678 * * *$ & & & & $2.897 * * *$ & .05 & -0.1091 \\
\hline CVIX & $(2.435)$ & $(.1445)$ & & & & $(.6521)$ & & \\
\hline
\end{tabular}

The method of estimation is the vector error correction model with two lags. The lag length was chosen by the HQ, SC, or AIC Criterion. In the first-stage the Johansen cointegration method is used for estimation of the long-run vector. In the second-stage, residuals from the first-stage are used in differenced form.

*Significance at $10 \%$ level.

$* *$ Significance at $5 \%$ level.

$* * *$ Significance at $1 \%$ level.

Oil becomes very significant predictor of the equity index in Canada using OLS estimation with coefficients ranging from 0.138 to 0.239 and significant at all conventional statistical levels. These coefficients remain positive when using JOH-ML but do not show statistical significance. The coefficients related to inflation Canada show a strong negative a significant $\beta$ of -3.57 and -4.86 again, marking a difference between the two countries in this study. Concentrating on the monetary variables impact on equity markets in Canada I am able to discover that changes in interest rates have a much different impact on equity markets in Canada. Both $\beta$ coefficients for BR and FF show a positive coefficient which is significant at conventional levels in both the OLS and JOH-ML results.

In the second-half of tables 9 and 10 the study focuses on the Canadian VIX index as the dependent variable. Results pertaining to CGDP and OIL in the study do not give conclusive results on the impact of these variables have on the VIX in Canada. The GDP coefficient indicates to have a negative impact on the CVIX but fluctuates considerably and does not show to be significant in most OLS models. Oil prices display a significant positive $\beta$ and in the JOH-ML estimates but lose such significant results in OLS estimates. Of interest to this study is the relationship monetary variables have on the CVIX. Strong results in both the OLS and JOH-ML estimates indicate that monetary variables do have an impact on Canadian VIX index. The BR and the FF coefficients suggest a negative relationship with $\beta$ displayed as -0.058 and -0.043 respectively in OLS estimates. The U.S. money supply also shows significance in both estimations indicating positive changes in USM2 lead to higher levels in the Canadian VIX.

Focusing on the far right column in table 10, which identifies the error-correction term (feedback coefficient), we can confirm that the feedback adjustments are negative and statistically significant for all the Canadian models. As in the U.S. models, the null hypothesis of these feedback adjustments being zero can be rejected at conventional statistical levels. When deviations from the long-run equilibrium occur it is mainly the equity index that adjusts to reestablish long-run equilibrium in our Canadian sample, rather than the included predicting variables. Table 10 also indicates that if the equity-market performance was higher than expected in the last period, in the current period it would be decreased by $0.9 \%$ to $1.5 \%$ to reestablish the long-run relationship between the stock-market performance and the included independent variables. Lastly, table 10 indicates that if the Canadian VIX index was higher than expected in the last period, in the current period it would be decreased by $1.1 \%$ to $\%$ to $1.4 \%$ find restore the long-run relationship between the CVIX and the independent variables. As in the U.S model the findings proposes that the included independent variables are (weakly) exogenous. The 
second implication is that unidirectional Granger causality going from the significant independent variables to the predicted variables is supported. In general the Canadian study finds long-run and short-run causation for output (CGDP), oil prices (OIL), inflation (CCPI) and interest rates (FF, BR) to both the TSX60 and the Canadian VIX index.

\section{Conclusion}

In investigating the impact of monetary policy changes on the U.S. and Canadian equity market performance, the paper controls for numerous variables and conducts multiple analyses. The research finds that the federal funds (U.S) and bank rate (Canada) have differing impacts on the equity markets in U.S. and Canada over the sample period. The U.S. models show a negative and significant coefficient while the Canadian models how a positive coefficient attached to the above mentioned interest rates. Secondly, the U.S VIX index does not seem to be affected by changes in monetary policy whereas Canadian VIX index are significantly impacted by changes in interest rate policy generated in both the U.S. and Canada in contrast to Souki (2008) who suggesting that shocks in monetary policy may have a stabilizing effect on the Canadian financial markets.

When focusing on the equity market index in the U.S. the average long-term parameter estimate across specifications for interest rate changes is -0.013 to -0.067 when monthly data are used. This suggests that tightening of monetary policy via interest rate changes significantly contribute to the explanation of variation in the S\&P 500. Secondly, when focusing on the VIX indices the average long-term parameter estimate for interest rate changes is 0.019 to 0.178 and insignificant at any conventional statistical levels suggesting that interest rate changes do not contribute to the explanation of variation in the U.S. VIX index.

Changing the focus to the Canadian equity market index the average long-term parameter estimate for interest rate changes is 0.051 to 0.059 . This suggests that tightening of monetary policy in Canada via interest changes significantly contribute to the explanation of variation in the TSX60 but in much different fashion when compared to the U.S. markets. Secondly, when focusing on the VIX indices in Canada the average long-term parameter estimate for interest rate changes is -0.106 to -0.058 and significant at conventional statistical levels suggesting that interest rate changes do in fact contribute to the explanation of variation in the Canadian VIX index.

Additionally, this study incorporates additional control variables such as output, inflation and oil prices. The results from these control variables show additional differences between the two countries of interest. First, oil prices play a very different role in both countries. Increases in the price of crude oil produces a positive impact on the equity markets in Canada but have a negative influence on U.S. equity markets. Further, crude oil prices do not influence the U.S. VIX indices but do show to contribute positively to the Canadian VIX when using JOH-ML regression models. Secondly, output as measured by industrial production in the U.S. and GDP in Canada show to have negative long run relationship with the VIX indices in both countries.

The results suggests that although the U.S. and Canadian financial markets are very similar the globalization of financial markets continue to evolve the response of monetary policy across the two countries may not remain static. This research can be extended further by adding additional asset markets such as real estate to better understand the impacts monetary policy has on each respective market.

\section{References}

Bakshi, G., \& Chen, S. (1996). Inflation, asset prices, and the term structure of interest rates in monetary economics. Review of Financial Studies, 9, 241-276. http://dx.doi.org/10.1093/rfs/9.1.241

Bernanke, B. S., \& Kuttner, K. N. (2005). What explains the stock market's reaction to federal reserve policy? Journal of Finance, 60(3), 1221-1257. http://dx.doi.org/10.1111/j.1540-6261.2005.00760.x

Bomfim, A. N. (2003). Pre-announcement effects, news effects, and volatility: Monetary policy and the stock market. Journal of Banking and Finance, 27, 133-151. http://dx.doi.org/10.1016/S0378-4266(01)00211-4

Chen, E. T., \& Clements, A. (2007). S\&P500 implied volatility and monetary policy announcements. Financial Research Letters, 4, 227-232. http://dx.doi.org/10.1016/j.frl.2007.07.002

Dickey, D., \& Filler, W. (1979). Distribution of the estimators for autoregressive time series with a unit root. Journal of American Statistical Association, 74, 427-431.

Dufour, M. M., \& Tessier, D. (2006). Short-run and Long-run Causality between Monetary Policy Variables and Stock Prices. Bank of Canada Working Paper No. 2006-39. Ottawa.

Elliott, G., Rothenberg, T. J., \& Stock, J. H. (1996). Efficient Tests for an Autoregressive Unit Root. Econometrica, 64(4), 813-836. http://dx.doi.org/10.2307/2171846 
Fama, E., \& Schwert, G. W. (1977). Asset returns and inflation. Journal of Financial Economics, 5(2), 115-146. http://dx.doi.org/10.1016/0304-405X(77)90014-9

Hess, P., \& Lee, B. (1999). Stock returns and inflation with supply and demand disturbances. The Review of Financial Studies, 12(5), 1203-1218. http://dx.doi.org/10.1093/rfs/12.5.1203

Johansen, S. (1988). Statistical analysis of cointegration vectors. Journal of Economics and Dynamic Control, 12, 231-254. http://dx.doi.org/10.1016/0165-1889(88)90041-3

Johansen, S. (1991). Estimation and hypothesis testing of cointegration vectors in Gaussian vector autoregressive models. Econometrica: Journal of the Econometric Society, 1551-1580. http://dx.doi.org/10.2307/2938278

Lastrapes, W. D. (1998). International Evidence on equity prices, interest rates, and money. Journal of International Money and Finance, 17(3), 372-406. http://dx.doi.org/10.1016/S0261-5606(98)00012-6

Li, Y. D., Iscan, T. B., \& Xu, K. (2010). The impact of monetary policy shocks on stock prices: Evidence from Canada and the United States. Journal of International Money and Finance, 29, 876-896. http://dx.doi.org/10.1016/j.jimonfin.2010.03.008

Lizzardo, R. A., \& Mollick, A.V. (2009). Do foreign purchases of U.S. stocks help the U.S. stock market? Journal of International Financial Markets, Institutions \& Money, 19, 969-986. http://dx.doi.org/10.1016/j.intfin.2009.08.002

Newey, W. K., \& West, K. D. (1987). A simple positive-definite heteroscedasticity and $\begin{array}{lllll}\text { auto-correlation-consistent } & \text { covariance matrix. Econometrica, } & \text { 55, }\end{array}$ http://dx.doi.org/10.2307/1913610

Ng, S., \& Perron, P. (1995). Unit root test in ARMA models with data dependent methods for the selection of the truncation lag. Journal of the American Statistical Association, 90, 268-281. http://dx.doi.org/10.1080/01621459.1995.10476510

Nikkinen, J., \& Sahlstrom, P. (2004). Impact of the federal open market committee's meetings and scheduled macroeconomic news on stock market uncertainty. International Review of Financial Analysis, 13, 1-12. http://dx.doi.org/10.1016/j.irfa.2004.01.001

Park, K., \& Ratti, R. A. (2000). Real activity, inflation, stock returns, and monetary policy. The Financial Review, 35(2), 59-78. http://dx.doi.org/10.1111/j.1540-6288.2000.tb01414.x

Patelis, A. D. (1997). Stock returns predictability and the role of monetary policy. Journal of Finance, 52(5), 1951-1972. http://dx.doi.org/10.1111/j.1540-6261.1997.tb02747.x

Phillips, P. C., \& Perron, P. (1988). Testing for a unit root in time series regression. Biometrika, 75(2), 335-346.http://dx.doi.org/10.1093/biomet/75.2.335

Souki, K. (2008). Assessing the effects of U.S. shocks on the Canadian economy using alternative identification models. North American Journal of Economics and Finance, 19(2), 193-213. http://dx.doi.org/10.1016/j.najef.2007.07.001

Siklos, P. L., \& Anusiewicz, J. (1998). The effect of Canadian and U.S. M1 announcements on Canadian financial markets, the crow years. Journal of Business and Economics, 50, 49-66. http://dx.doi.org/10.1016/S0148-6195(97)00053-2

Thorbecke, W. (1997). On stock market returns and monetary policy. Journal of Finance, 52(2), 635-654. http://dx.doi.org/10.1111/j.1540-6261.1997.tb04816.x

\section{Notes}

Note 1. Sources: Statistics Canada, CANSIMII database and U.S. Census Bureau, Foreign Trade Division.

Note 2. See Hess and Lee (1999) or Lizzardo and Mollick (2009) for further details on this relationship.

\section{Appendix A}

\section{Data Description and Sources}

Canadian Data via CANSIMII, unless otherwise stated.

- Industrial production: Table 379-0031 Gross domestic product (GDP) at basic prices. 
- Consumer price index: Table 326-0020 Consumer Price Index, monthly (2002=100).

- Overnight interest rate: Table 176-0043 Financial market statistics, Bank of Canada, monthly.

- Stock Prices (TSE300): Table 377-0003 Business leading indicators for Canada, monthly.

- Oil Prices: Crude Oil Prices: West Texas Intermediate (WTI), series ID: MCOILWTICO, monthly.

- Consumer Sentiment (VIX) (MVX): The S\&P/TSX 60 VIX® index (VIXC) Pre-2010 (MVX) https://www.m-x.ca/indicesmx_vixc_en.php

U.S. Data via U.S. Federal Reserve of St Louis (FRED), unless otherwise stated.

- Industrial Production: Industrial Production Index, series ID: INDPRO.

- Consumer price index: Consumer Price Index - All Items, series ID: CPIAUCSL, monthly.

- Federal funds rate: Effective federal funds rate, series ID: FEDFUNDS, monthly.

- Money Supply (M2): Money Stock -M2, series ID: M2SL, monthly.

- Stock Prices (SP500): Standard \& Poor's composite index (monthly average). Via Robert Shiller's webpage at http://www.econ.yale.edu/shiller

- Oil Prices: Crude Oil Prices: West Texas Intermediate (WTI), series ID: MCOILWTICO, monthly.

- Consumer sentiment: CBOE Volatility Index: VIX®, series ID: VIXCLS, monthly.

\section{Copyrights}

Copyright for this article is retained by the author(s), with first publication rights granted to the journal.

This is an open-access article distributed under the terms and conditions of the Creative Commons Attribution license (http://creativecommons.org/licenses/by/3.0/). 